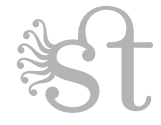

\title{
Nanotechnology: a new regime for the public in science?
}

\author{
Bernadette BenSAUde-VINGEnT
}

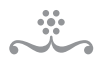

\begin{abstract}
AB STRACT
"Public engagement in science" is one of the buzzwords that, since 2000 , has been used in nanotechnology programs. To what extent does public engagement disrupt the traditional relations between science and the public? This paper briefly contrasts the traditional model of science communication - the diffusionist model - that prevailed in the twentieth century and the new model - the participatory model - that tends to prevail nowadays. Then it will try to disentangle the assumptions underlying the public dialogue initiated about nanotechnology, and conclude that nanotechnology actually develops a managerial model of society.
\end{abstract}

KEYwords • Science. Technology. Public engagement. Governance. Stakeholders.

\section{INTRODUCTION}

Throughout the twentieth century, there was a one-way traffic between science and the public, from the scientific communities toward the society at large. This top-down communication process, known as science popularization, has been critically analyzed by a number of scholars over the past decades (cf. Shinn \& Whitley, 1985; Hilgartner, 1990; Bensaude-Vincent, 1997; Bucchi \& Trench, 2008); and, at the same time, "dialogue" and "public engagement in science" gradually became fashionable buzzwords. In the context of the crisis about BSE (bovine spongiform encephalopathy, or "mad-cow disease"), and controversies about genetically modified food, there seems to have emerged a new model of relations between science and the public that can be captured by the ideal of citizen science (cf. Irwin, 1995). Since 2000, this movement has been illustrated by the nanotechnology initiatives that have recommended engaging with the public upstream from the outset, long before technological applications enter the market. This has led to experimentation with a whole spectrum of procedures that are designed to involve the public: public consultations, citizen juries, consensus conferences, focus group, hybrid forums etc. Does this mean that nanotechnology fosters a new regime of relations between science and the public? 
In this article, I will first briefly contrast the traditional model of science communication - the diffusionist model - that prevailed in the twentieth century and the new model - the participatory model - that tends to prevail nowadays. Then I will try to disentangle the assumptions underlying the public dialogue initiated about nanotechnology. Finally, I point to the limitations of efforts to open science to the public.

\section{DifFUSIONIST AND PARTICIPATORY MODELS}

The practices of science popularization in the twentieth century embody the diffusionist model of relations between science and the public. They were rooted in a number of tacit assumptions, which legitimized attempts at spreading scientific views among the public at large (cf. Bensaude-Vincent, 2009a). Basically, the diffusionist model of science popularization rests on the view that, due to the advancement of knowledge and the formalization of scientific discourses, there is an increasing gulf between scientists and the public (cf. Bensaude-Vincent, 2001). ${ }^{\mathbf{1}}$ The alleged gulf between the scientific elite and the lay public calls for mediators, or popularizers, whose task is to bridge the ever expanding gap in order to gain public support for scientific research. Their task is to transfer knowledge, or to translate scientific language into daily language, or to report on scientific news without paying attention to public concerns. Members of the public itself are not invited to participate in the scientific endeavour as amateurs. Rather the public is considered to be a passive audience, made up of consumers of science and technology characterized by their lack of knowledge. It was also assumed that increasing the public understanding of science would automatically generate more favourable attitudes towards science.

This view of the public as "those-who-do-not-know" supports a specific view of science as an autonomous enterprise. Scientific communities are the unique source of legitimate knowledge, as its impartiality is guaranteed by the peer review system. Scientific judgments are independent from public opinion as well as from political or religious powers. Science and technology are supposedly free from social and moral values, being only submitted to epistemic norms such as truth, simplicity etc. (cf. Lacey, 2008). Over the past decades, however, the divorce between science and public opinion has been questioned.

On the one hand, recent controversies have revealed the social dimension of technoscientific issues. While the public was kept out of scientific issues during the

1 In reality, popularization has contributed to isolating scientists from the rest of the world, and to turning science into a sacred all-powerful deity - thus increasing, rather than decreasing, the alleged gap. 
golden age of theoretical physics, when relativity theory and quantum physics were the main concern, everyone feels that they are affected by the advances of information technology, genetic engineering, and nanotechnology. Technosciences impact on our daily lives; they change our way of knowing, of living, of procreating, as well as of dying. New actors have emerged; they include ethics committees, policy makers, industrial companies, banks, users' groups, consumer associations, environmental activists, insurance companies, trade unions, and NGOs. With so many actors on the stage, the mythical gulf between science and the public has vanished. The diffusionist model has given way to the participatory model. Whereas science communication was practiced in the name of science, there is now a strong urge to develop better relations between scientists and civil society in the name of democracy.

On the other hand, in this new context of participatory science, the public is no longer viewed as a passive audience. Even the use of the generic term "public", often used to describe an undifferentiated mass of passive consumers, has been superseded by the use of the political term "citizens", which suggests a variety of motivated individuals or informed groups, acting as responsible actors and members of civil society. The concept of "scientific citizen" emerged through public consultations, consensus conferences, focus groups, and hybrid forums that gradually tended to replace the oneway process of science popularisation (cf. Bucchi \& Trench, 2008). In such dispositifs, the mass of passive consumers referred to as the public has been replaced by a variety of motivated individuals or informed groups, who are acting as citizens aware of their civil rights; and social scientists are usually called to act as mediators or "third persons" in place of science popularizers.

Furthermore, two decades of interactive communication have changed the epistemic culture. Science and technology are no longer viewed as value-free. Under the pressure for democratization, the ideal of the pursuit of truth as a neutral or amoral activity, presupposing a clear boundary between facts and values has gradually been replaced by the ideal of science for the pursuit of specific societal or economic goals (cf. Kitcher, 2001; Carrier, et al., 2008). Truth in itself is no longer considered a legitimate goal. It has to be a significant truth. This regime of research agendas, defined relative to societal or economic values, is a major feature of technoscience (cf. Bensaude-Vincent, 2009b). Scientific research has now become legitimized by all sorts of potential benefits that it allegedly can bring to society, rather than by the advancement of knowledge for its own sake. In addition, the scientific elite is no longer viewed as homogeneous and speaking with a single voice. Recent controversies have amply demonstrated that experts do not necessarily hold the same views on the scientific issues that the public is concerned with. Expertise is badly needed on issues such as genetically modified crops or climate change, and at the same time it is hotly contested 
(cf. Nowotny, 2003). Societal concerns have gradually changed the traditional criteria of evaluation in scientific communities: although the truth value warranted by the peer review system still prevails in the evaluation of publications, when it comes to evaluation of research proposals and funding, "social robustness" is also taken into account (cf. Weingart, 2008). Whatever the vagueness of this notion, it clearly expresses the intrusion of societal concerns into the practices of science.

\section{NANOTEGHNOLOGY AND PUBLIC ENGAGEMENT}

In Europe, efforts to engage the public upstream started as early as 2004, when the report by the Royal Society and the Royal Academy of Engineering, Nanoscience and nanotechnology: opportunities \& uncertainties (Royal Society, 2004), recommended that "government initiate adequately funded public dialogue around the development of nanotechnologies (...)". ${ }^{2}$ Following this, a citizen jury was organized in the United Kingdom, and a nanotechnology engagement group was set up there in 2005. The UK initiative was followed by a number of similar attempts at engaging the public in Germany, France, the Netherlands, Austria, Switzerland and other countries. Agreat variety of procedures for public dialogue have been experimented with (cf. Bucchi \& Trench, 2008), in part inspired and supported by the research programs implemented by the nano-initiatives on ethical, legal and societal aspects of nanotechnology as well as on their environmental and health impacts.

Ten years later, what kind of results do we get from these active campaigns for increasing citizens' participation in science and technology? In its preliminary report, presented in 2006, the UK Nanotechnology Engagement Group (NEG) identified two key challenges for developing a true democratic involvement of the public on nanotechnologies: first, to move from the current dispositifs such as citizen juries that involve only a small number of citizens to larger procedures involving larger numbers of people; and, second, to effectively integrate public engagement into institutional Research \& Development (R\&D) processes in both the public and the private sectors (cf. NEG, 2006). Its final report, entitled Democratic technologies? (cf. Gavelin \& Wilson, 2007), emphasized the growing awareness in government and in society of the importance of developing trusting relationships between science and citizens; it also emphasized the limitations of current efforts.

2 The Report's other recommendations included: "all relevant regulatory bodies consider whether existing regulations are appropriate to protect humans and the environment from the hazards (...)", and "an extensive program of research into public attitudes to nanotechnologies". 
In fact, neither of the two challenges identified in 2006 has yet been met. Citizen juries and consensus conferences tend to spread the fiction of an average, reasonable citizen, thus minimizing the role of activists. In addition, scaling-up public involvement seems quite difficult (cf. Scheufele \& Ross, 2011). While it seems rather easy to involve a few concerned citizens, it seems much more problematic to engage the mass public. For instance, the brave attempt to launch a national public debate about nanotechnology in France in 2009 ended up as a fiasco (cf. Commission, 2012). Of the seventeen meetings scheduled all over the country for six months, only a few could be held, because they were disrupted by groups of anti-nano activists who protested against French science policy and denounced what they identified as illusory democratic dialogue (cf. Sciences, 20). The debate only reinforced the antagonism between the technophilic elite and their technophobic opponents.

As for the integration of public engagement into R\&D institutions, the process seems even more problematic. Although a few research agencies involve a number of representatives of NGOs and citizen associations in their steering committees (cf. Epstein, 1996; 2007), the role of such groups in the process of decision-making seems quite modest.

\section{Demogratic governange?}

Rather than surveying the various efforts made in various countries to engage the public in general, ${ }^{3}$ I will try to characterize the motivations and expectations that prompt a number of actors into efforts for engaging the public upstream in nano-research. Many of those who have promoted nanotechnology initiatives seem to be primarily concerned with avoiding the kind of social backlash that Europe experienced with GMOs food. For them, involving the public upstream is no more than preparing society for the societal changes that, it is thought, will inevitably occur. For instance, the 2002 US report, Converging technologies for improving human performance (cf. Roco \& Bainbridge, 2002), clearly stated:

It is essential to prepare key organizations and societal activities for the changes made possible by converging technologies. Activities that accelerate convergence to improve human performance must be enhanced, including focused research and development, increased technological synergy from the nanoscale, develop-

3 For examples of consensus conferences, see <http://www.co-intelligence.org/P-ConsensusConference1.html> (accessed: 27/Jan./2012); and of citizen juries, see <http://www.ncl.ac.uk/peals/dialogues/juries.htm> (accessed: $27 / \operatorname{Jan} . / 2012)$. 
ing of interfaces among sciences and technologies, and a holistic approach to monitor the resultant societal evolution (Roco \& Bainbridge, 2002, executive summary, p. x).

The advocates of the nanotechnology era, their ultimate goal being the social acceptance of nanotechnology, are never short of extravagant promises (clean energy, enhancing medicines, immortality etc.) that have been repeated ad libitum in order to attract public interest and private investors.

The report endorses that research programs in nanotechnology involve social scientists as experts in public opinion with the expectation that they will "monitor" the public or "engineer" a society living with nano-products, where the involvement of social scientists and ethicists is meant to smooth the pathway and to get rid of obstacles for technological innovations to diffuse through the society at large. In brief, this initiative incorporates a technocratic attitude, based on the credo of technological determinism. Society is shaped by technological push, and the role of the government is to set the conditions for technological changes to occur. Promoting and funding research in nanotechnology is not considered to be a matter of choice; no debate is needed about it, for it is presented as the unique pathway of development, essential to the future for which societies need to get prepared. Even if they encourage public engagement, the leaders of the nano-initiatives still consider the public as a mass of consumers of technological innovations, and they still believe that more information about nanotechnology is sufficient to gain public support (cf. Brown, 2009).

Despite the role ascribed to social scientists by the promoters of the US nanoinitiative, social scientists have their own motivations for embarking upstream in nanoresearch programs. For them, nanotechnology provides a test case for exploring how democratic societies are being reshaped by their technological choices and how they redefine their identity through technological choices. It is an opportunity to implement the STS (Science and Technology Studies) basic credo of the co-construction of science and society. Far from assuming technological determinism, these social scientists, who are embedded in nano-research programs, are confident that it is possible to open scientific and technological choices to social values and expectations. For instance, a report was issued in 2004, on Convergent technologies for the European knowledge society (CTEKS), and it clearly contrasts the technocratic vision of the US program to the democratic vision of the European approach (cf. Nordmann, 2004). Nanotechnology and convergent technologies (information technologies, biotechnologies and cognitive science) would be shaped by social pull rather than by technological push. European values, such as human rights and social solidarity should be the determining factors. Far from being supposed value-free, science and technology are loaded with 
non-epistemic values and citizens have a right to ensure that technoscientific choices respect their social and moral values.

Thus "engaging the public" seems to be a buzzword that covers quite opposite visions of the role of society in science and technology. How can a process of dialogue work when the various protagonists have such diverging expectations?

\section{A MANAGERIAL MODEL}

Bringing together apparently contradictory visions seems to be the rule of the game called "governance of science and technology". For science policy makers at the European Council nanotechnology provides a niche for implementing the "knowledge-based economy and society", the keyword of the strategy decided by the European Council meeting in Lisbon in March 2000 (cf. European Council, 2000). The Lisbon strategy in itself is based on an oxymoron, since it tries to achieve two hardly reconcilable goals: "making the European union the most competitive economy in the world", and "securing social cohesion" through ensuring full-employment and combating social exclusion. A third goal, another oxymoron: "sustainable development", was added the next year at the Göteborg meeting of the Council (cf. European Council, 2001). All subsequent European Council papers confirm the research agenda toward competitiveness, growth and sustainability (cf., for example, European Commission, 2010). The basic expectation is that nanotechnological innovations will help decoupling economic growth and consuming natural resources. "Green nanotechnology" is supposed to provide clean and renewable energy, to reduce industrial pollution and to alleviate the burden of agriculture and industry on the planet. In other terms, it is tacitly assumed that the oil crisis and most environmental issues can be overcome thanks to technological solutions (cf. Schwarz, 2009).

This technological optimism in the European Council is not, however, based on technological determinism. The technology push has to be regulated and carefully monitored in a democratic process of governance. The European initiative in nanotechnology and convergent technologies is shaped along a model of participatory democracy, where citizens are redefined as "stakeholders", or partners of technoscientific ventures. The term "stakeholder" was coined in the business world, on the model of "shareholders". Like the term "governance", which also came into use in the business world, it betrays the dominance of the corporate model on European science policy. ${ }^{4}$

4. According to the Business Dictionary, <http://www.businessdictionary.com/definition/stake holder.html > (accessed: 27 /Jan./2012), a stakeholder is a "person, group, or organization that has direct or indirect stake in an organization 
This style of governance (cf. Bruno, 2008, 2011) requires foresight exercised as a planning and management tool. It also requires regular meetings between stakeholders scientists, industrial people, NGOs, insurance companies, ethicists etc. - for monitoring European science and technology policy along the lines of the Lisbon agenda and European values. The basic assumption underlying this iterative, endless process is that critical discussion leads to better technological choices. The European expectation to reconcile science and democracy rests on the idea that social critique is constructive rather than disruptive. According to Sheila Jasanoff, the European approach is based on "informed dissent" (Jasanoff, 2010).

\title{
Concluding REMARKS
}

Nanotechnology provides a test case for new ideas about public engagement, and science and democracy. There is a strong urge from science policy makers for more responsible scientists, aware of the consequences of their research for the society at large. Ethical societal and environmental impacts have to be taken into account upstream, at the level of basic research long before applications enter the market. Although one can reasonably admit that both science and civil society are changing, it would be naive to assume that scientific practices are open to democratic processes and that the view of a malleable, irrational, unpredictable public is dead and replaced by the view of responsible citizens negotiating scientific and technological choices. Still one major conviction has emerged through social experimentations about nanotechnology: science and technology are social and political concerns.

\author{
Bernadette Bensaude-Vingent \\ Professor, UFR of Philosophy, \\ University of Paris 1 and University Institute of France, \\ Paris, France. \\ bensaude@club-internet.fr
}

\begin{abstract}
because it can affect or be affected by the organization's actions, objectives, and policies. Key stakeholders in a business organization include creditors, customers, directors, employees, government (and its agencies), owners (shareholders), suppliers, unions, and the community from which the business draws its resources. Although stakeholding is usually self-legitimizing (those who judge themselves to be stakeholders are de facto so), all stakeholders are not equal and different stakeholders are entitled to different considerations. For example, a firm's customers are entitled to fair trading practices but they are not entitled to the same consideration as the firm's employees".
\end{abstract}


NANOteghnology: A NeW REgime For the PUblic in SGienge?

\section{REFERENGES}

Bensaude-Vincent, B. In the name of science. In: Krige, J. \& Pestre, D. (Ed.). Science in the twentieth century. Amsterdam: Harwood Publishers, 1997. p. 319-38.

. A genealogy of the increasing gap between science and the public. Public Understanding of Science, 10, p. 99-113, 2001.

. A historical perspective on science and its “others". Isis, 100, p. 359-68, $2009 \mathrm{a}$.

Les vertiges de la technoscience. Paris: Éditions la Découverte, 2009b.

Brown, S. The new deficit model. Nature Nanotechnology, 4, p. 609-11, 2009.

Bruno, I. À vos marques, prêts, cherchez! la stratégie européenne de Lisbonne: vers un marché de la recherche. Paris: Éditions du Croquant, 2008.

. Comment gouverner un "espace européen de la recherche" et des "chercheurs entrepreneurs"? Le recours au management comme technologie politique. Innovations, 36, p. 65-82, 2011.

Bucchi, M. \& Trench, B. Handbook of public communication of science and technology. London: Routledge, 2008.

GARRIER, M. et al. (Ed.). The challenge of the social and the pressure of practice: science and values revisited. Pittsburg: University of Pittsburg Press, 2008.

Commission Particulière du Débat Public Nanotechnologies. Available at: 〈http://debatpublic-nano. org $>$. Accessed: 27/Jan./2012.

EPSTEIn, S. Impure science: AIDS, activism and the politics of knowledge. Berkeley: University of California Press, 1996.

. Inclusion: the politics of difference in medical research. Chicago: University of Chicago Press, 2007.

European Commission. Europe 2020, 2010. Available at: <http://ec.europa.eu/europe2020/index_en. htm>. Accessed: 27/Jan./2012.

European Council, Lisbon. Presidency conclusions, 2000. Available at: <http://www.europarl.europa.eu/ summits/lisı_en.htm>.Accessed: 26/Jan./2012.

European Council Göteborg. Presidency conclusions, 2001. Available at: <http://ec.europa.eu/governance/ impact/background/docs/goteborg_concl_en.pdf >.Accessed: 26/Jan./2012.

GaVelin, K. \& Wilson, R. Democratic technologies? The final report of the nanotechnology engagement group. London, 2007. Available at: <http://www.involve.org.uk/wp-content/uploads/2011/o3/DemocraticTechnologies.pdf >. Accessed: o9/Jan./2012.

Hilgartner, S. The dominant view of popularization: conceptual problems, political uses. Social Studies of Science, 20, p. 519-39, 1990.

Inwin, A. Citizen science: a study of people, expertise, and sustainable development. London: Routledge, 1995.

JaSAnoff, S. Designs on nature, science and democracy in Europe and the United States. Princeton: Princeton University Press, 2010.

Kitcher, P. Science, truth, and democracy. Oxford: Oxford University Press, 2001.

Krige, J. \& Pestre, D. (Ed.). Science in the twentieth century. Amsterdam: Harwood Publishers, 1997.

Lacey, H. Valores e atividade científica 1. São Paulo: Associação Filosófica Scientiae Studia/Editora 34, 2008.

NEG (Nanotechnology Engagement Group). Policy Report 1 . 2006. Available at: <http://nanoandsociety.com /ourlibrary/documents/NEGPolicyReportı.pdf >. Accessed: 26/Jan./2012.

Nordmann, A. Converging technologies; shaping the future of European societies. Report of the European Union High-Level Expert Group. Brussels, 2004. Available at: <http://www.ntnu.no/2020/final_report_ en.pdf>. Accessed: 09/Jan./2012. 
Nowotny, H. Democratizing expertise and socially robust knowledge. Science and Public Policy, 3o, 3, p. $15^{1-6,2003 .}$

Roco, M. \& BAinbridge, W. S. (Ed.). Converging technologies for improving human performance: nanotechnology, biotechnology, information technology and cognitive science. National Science Foundation. Arlington, 2002. Available at: 〈http://www.wtec.org/ConvergingTechnologies/1/NBIC_report.pdf >. Accessed: 09/Jan./2012.

Royal Society. Report of The Royal Society \& The Royal Academy of Engineering, Nanoscience and nanotechnologies: opportunities and uncertainties. London, 2004. Available at: <http://royalsociety.org/uploaded Files/Royal_Society_Con tent/policy/publications/2004/9693.pdf >.Accessed: 09/Jan./2012.

Sciences et Démocratie. Débats de societé sur les enjeux des technologies et des sciences. Available at: <http:/ /www.sciences-et-democratie.net/mots-cles/cndp>. Accessed: 27/Jan./2012.

Sheufele, D. A. \& Ross, J. E. Modern citizenship or policy dead end? Evaluating the need for public participation in science policy making, and why public meetings may not be the answer. Joan Shorenstein Center on the Press, Politics and Public Policy, Research Paper Series. \#R 34, 2011. Available at: 〈http://www.hks.harvard.edu/presspol/publications/papers/research_papers/r34_scheufele.pdf〉. Accessed: 26/Jan./2012.

Shinn, T. \& Whitley, R. (Ed.). Expository science: forms and functions of popularization. Dordrecht: D. Reidel, 1985 .

Schwarz, A. Green dreams of reason: green nanotechnology between visions of excess and control. NanoEthics, 3, p. 109-18, 2009.

Weingart, P. How robust is "socially robust" knowledge? In: CARrier, M. et al. (Ed.). The challenge of the social and the pressure of practice: science and values revisited. Pittsburgh: University of Pittsburg Press, 2008. p. 131-45. 